\title{
KAJIAN PEMBERIAN KALSIUM (Ca) UNTUK MEMPERTAHANKAN SIFAT KIMIA BUAH SAWO
}

\author{
Yekti Sri Rahayu - Fakultas Pertanian Universitas Wisnuwardhana Malang \\ Email:yektisr@ymail.com
}

Idiek Donowarti - Fakultas Pertanian Universitas Wisnuwardhana Malang

Email: idiek_donowati@yahoo.com

\begin{abstract}
The research aims to study the best Calcium solution resource and the optimum Calcium consentration for maintaining chemical characteristic sapodilla fruit. The research was done in Central Laboratory of Agriculture Department, University of Wisnuwardhana, Malang Regency. The research methode use Random Completed Design (RCD) that arranged in factorial, consist of 2 factors and repeated 3 times. The first was the kinds of Calcium sources: $\mathrm{A} 1=\mathrm{CaCl}_{2} ; \mathrm{A} 2=\mathrm{Ca}(\mathrm{OH})_{2 ;}$, the second was concentration of Calcium sources: $\mathrm{K} 1: 0 \%$; K2 : $0.2 \%$; K3 : 0,4 \% ; K4 : 0,6 \%. Sapodilla was soaked in $\mathrm{CaCl}_{2}$ solution and $\mathrm{Ca}(\mathrm{OH})_{2}$ with concentration according to the treatment, in vacuum pressure in the vacuum tanki -60 $\mathrm{cm} \mathrm{Hg}$ to $-70 \mathrm{cmHg}$. The data was analyzed by ANOVA test, followed by Least Significant Difference Test at 5\% level. Results show that Sapodilla fruit Soaking in a solution of $\mathrm{Ca}(\mathrm{OH})_{2} 0.6 \%$ causes the fruit has the lowest value of total soluble solids (17.00 0Brix), the lowest reducing sugar $(22.580 \%)$, the highest starch content is $1.70 \%$, the lowest $\mathrm{pH}(3.05)$, the highest calcium content of $80.02 \mathrm{mg} / 100 \mathrm{gr}$, and. Soaking $\mathrm{CaCl}_{2} 0.6 \%$ gave the fruit has the lowest value of total soluble solids (17.06 ${ }^{0}$ Brix), the highest starch content is $1.73 \%$, the lowest $\mathrm{pH}(3.71)$, the lowest tannin content that is equal to $0.249 \mathrm{mg} / 100 \mathrm{gr}$, the highest water content $(81.696 \%)$ and highest shelf life that equal to 6 days.

Key word: Sapodilla fruit, calcium, chemical characterisctic
\end{abstract}

\begin{abstract}
ABSTRAK
Penelitian ini bertujuan untuk mempelajari sumber kalsium terbaik dan konsentrasi kalsium optimal untuk mempertahankan karakteristik kimia buah sawo. Penelitian dilakukan di Laboratorium Terpadu Fakultas Pertanian Universitas Wisnuwardhana, Malang. Metode Penelitian menggunakan Rancangan Acak Lengkap (RAL) yang disusun secara faktorial, terdiri dari 2 faktor dan diulang 3 kali. Faktor pertama adalah jenis sumber Kalsium: $\mathrm{A} 1=\mathrm{CaCl}_{2} ; \mathrm{A} 2=$ $\mathrm{Ca}(\mathrm{OH})_{2}$; yang kedua adalah konsentrasi sumber Kalsium: K1: 0\%, K2: 0,2\%; K3: 0,4\%; K4: 0,6\%. Sawo direndam dalam larutan $\mathrm{CaCl}_{2}$ dan $\mathrm{Ca}(\mathrm{OH})_{2}$ dengan konsentrasi sesuai perlakuan, sawo direndam dalam larutan $\mathrm{CaCl}_{2}$ dan $\mathrm{Ca}(\mathrm{OH})_{2}$ dengan konsentrasi sesuai perlakuan, pada tekanan vacum dalam tanki - $60 \mathrm{~cm} \mathrm{Hg}$ sampai dengan - $70 \mathrm{~cm} \mathrm{Hg}$. Masing-masing larutan dipakai untuk merendam selama 10 menit. Data dianalisis dengan uji ANOVA, dilanjutkan dengan uji Beda Nyata Terkecil pada taraf 5\%. Hasil penelitian menunjukkan bahwa perendaman buah sawo dalam larutan $\mathrm{Ca}(\mathrm{OH})_{2} 0,6 \%$ menyebabkan buah mempunyai nilai total padatan terlarut terendah ( $\left.17,00{ }^{\circ} \mathrm{Brix}\right)$, gula reduksi terendah $(22,580 \%)$, kandungan pati tertinggi yaitu $1,70 \%, \mathrm{pH}$ terendah $(3,05)$, kadar kalsium tertinggi sebesar 80,02 mg/100gr. Perendaman $\mathrm{CaCl}_{2}$ 0,6\% memberikan total padatan terlarut terendah $\left(17,06^{\mathbf{0}} \mathrm{Brix}\right)$, kandungan pati tertinggi $1.73 \%, \mathrm{pH}$ terendah $(3,71)$, kadar tanin terendah yaitu sebesar $0,249 \mathrm{mg} / 100 \mathrm{gr}$, kadar air tertinggi $(81,696 \%)$, dan umur simpan tertinggi yaitu rata-rata setara 6 hari.

Kata kunci: buah sawo, kalsium, sifat kimiawi
\end{abstract}

